\title{
MORPHOFUNCTIONAL CONDITION OF THE HARDERIAN GLAND OF CHICKENS DURING THE POST-VACCINE IMMUNITY TO INFECTIOUS BRONCHITIS
}

\author{
S. V. Guralska, T. F. Kot, O. V. Pinskyi, V. M. Sokolyuk, T. S. Budnik \\ Zhytomyr National Agroecological University, Zhytomyr \\ 7, Staryi Boulevard, Zhytomyr, 10008
}

E-mail: guralska@ukr.net*,tkotvet@ukr.net,pinsky.o.v@gmail.com,vmsokoluk@gmail.com,tatjanabudnik@ukr.net

Received September 24, 2019 / Received February 19, 2020 / Accepted March 20, 2019

\begin{abstract}
Aim. To find out the contents and placement of $\mathrm{CD}^{+}, \mathrm{CD}^{+}, \mathrm{CD}^{2} 5 \mathrm{RA}^{+}, \mathrm{CD} 20^{+}$-lymphocyte subpopulations and morphocytochemical architecture of the harderian gland in clinically healthy chickens and for vaccination against infectious bronchitis. Methods. Anatomical, histological, immunohistochemical, optical, morphometric and variational-statistical. Results. The obtained morphometric study results showed that the area of secretory lobules and lymphoid formations was significantly larger in the harderian gland of vaccinated 40-, 90- and 110-day-old chickens. Moreover, the organ size correlates significantly with the development of lymphoid formations, since the area of the secretory lobules in the gland of the experimental group chickens does not differ from that of the control group. Immunohistochemical studies have shown that the number of lymphocytes with $\mathrm{CD} 20^{+}$markers was characterized by a reliable $(\mathrm{P}<0.001)$ increase in $\mathrm{B}-1 y m p h o c y t e s$ in the harderian gland of the vaccinated chickens of all ages. Lymphocytes with $\mathrm{CD}^{+}$markers were not detected in the gland of vaccinated 8- and 20-day-old chickens. According to cytomorphometric studies, their number in vaccinated 40-, 90- and 110-day-old chickens was significantly $(\mathrm{P}<0.001)$ higher compared to intact birds $-2.11,2.38$ and 2.96 times, respectively. Conclusions. The data on the composition of lymphocytes with $\mathrm{CD} 4^{+}, \mathrm{CD} 8^{+}$,

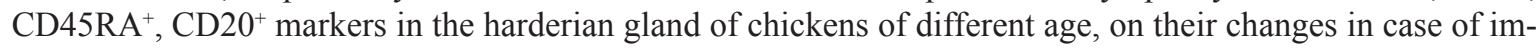
munization against infectious bronchitis were obtained, and the role of certain clusters at different stages of the immunity formation was determined. The information on the structure, patterns of growth and development of the harderian gland of chickens, which demonstrates the incompleteness of its morphogenesis at the early stages of the postnatal ontogenesis period that should be taken into account during the compilation of vaccine prophylaxis programs, has been supplemented.
\end{abstract}

Key words: pathomorphology, natural T-helper cells, T-cytotoxic cells, helper-type immunodeficiency, humoral immunity, foreign antigen, vaccination.

DOI:

\section{INTRODUCTION}

Infectious bronchitis (bronchitis infectiosa) - a highly contagious disease of chickens of different age (Alazawy A et al 2017, Habibi M et al 2017), caused by coronavirus (RNA-containing virus from Coronaviridae family) (Bande $\mathrm{F}$ et al 2015), is manifested in respiratory, nephroso-nephritic and reproductive forms (Cook J et al 2012, Bru T et al 2017, Karimi V et al 2019) and leads to considerable economic loss for poultry farms (Bande $\mathrm{F}$ et al 2015, 2017).

(C) S. V. GURALSKA, T. F. KOT, O. V. PINSKYI, V. M. SOKOLYUK, T. S. BUDNIK, 2020
The vaccination against avian infectious bronchitis (AIB) has been used for over half a century (Cook J et al 2012). The principal place in the complex of measures, aimed at prevention and elimination of infectious bronchitis, is given to specific prophylaxis using live and attenuated vaccines (Bru T et al 2017, Guralska S, Budnik T 2020), as general veterinary and sanitary measures do not ensure complete elimination of AIB at poultry farms (Ali A et al 2018).

The poultry breeding industry faces the challenge on the background of global crisis of food safety. Infectious bronchitis is one of the most common viral infections, causing enormous global economic loss for 
poultry breeding. The agent of infectious bronchitis is a virus with a great capability of mutation and recombination, thus capable of generating new strains of virus which are hard to control. There are many AIB strains in the world, including Massachusetts strains, 4/91, D274 and QX (Bande F et al 2017). Thus, the agent of the disease has numerous serotypes, differing in terms of antigens (Bande F et al 2015, Zhao W et al 2017). Therefore, while selecting the vaccine, one should take into consideration which serotype of the virus circulates in the region (Sarah E et al 2014, Valastro V et al 2016).

Live attenuated virus vaccines are available and so far have been reliable in controlling AIB-caused diseases (Ball C et al 2017). These vaccines contain AIB strains, such as Massachusetts, Connecticut, Arkansas and their combinations, ensuring protection from almost all the field strains of AIB (Ovchinnikova E et al 2011).

Despite actual achievements in studying immune responses of birds at specific prophylaxis of AIB, many issues of immunogenesis and, in particular, cell-mediated immunity, are yet to be determined in fine detail (Guralska S, Budnik T 2020, Gurjar R et al 2013, Jia $Z$ et al 2014). The data about immunomorphological changes in the organism of chickens in case of their vaccination against AIB are scarce.

Despite the achievements in immunomorphology, much is still to be determined about immune responses of mucous membranes of birds. The replication of the infectious bronchitis agent in the harderian gland affects the development of the immune response, which is characterized by the production of specific IgA. In addition, upper respiratory ways are the primary place of replication. The replication of AIB virus and the primary infection start in the epithelium of the harderian gland, trachea, lungs and air sacs, then kidneys, urinogenital organs and gastrointestinal tract, which causes damage and disease development (Gurjar R et al 2013).

It is believed that the harderian gland participates in different functions. Immune response has an important place among them (Jahan M et al 2018). Many authors assume that the harderian gland is a peripheral lymphoepithelial organ, which, together with spleen, cloacal sac and caecal glands, composes the system of immune organs, defining both general and local immunity (Jahan $M$ et al 2006, Khan M et al 2007).

The aim of the work was to investigate the morphofunctional condition of the harderian gland in chick- ens at vaccination for prophylaxis purposes. It also involved determining quantity indicators and specificities of the nature of marker-positive cells at norm to obtain the data about the composition of differentiation clusters in the harderian gland of chickens of different age and in case of vaccination.

\section{MATERIALS AND METHODS}

One-day-old Hisex brown cross chickens (q) were selected for the experiment at the premises of Starosolotvynska Ptakhofabryka ALLC in Berdychiv district of Zhytomyr region, divided into two groups of 70 birds each by the assimilation principle. The first group was control, clinically healthy chickens; the second group was experimental, here the chickens were vaccinated according to the vaccination schedule for replacement chickens using live lyophilized vaccine of H-120 strain of Massachusetts serotype (Intervet, Netherlands) (twice, on Days 1 and 30), using live lyophilized vaccine of 4-91 strain (Intervet, Netherlands) (twice, on Days 13 and 80), and inactivated vaccine against infectious bronchitis, Newcastle disease and egg drop syndrome (Intervet, Netherlands) (once, on Day 100).

The investigations of morphofunctional condition of the harderian gland involved the determination and analysis of age-related changes: anatomic (absolute weight, relative weight), histological (area of lymphoid formations, area of secretory lobules, area of connective tissue foundation) and immunohistochemical (content, placement and number of subpopulations of lymphocytes with surface markers $\mathrm{CD} 4^{+}, \mathrm{CD} 8^{+}, \mathrm{CD} 45 \mathrm{RA}^{+}$ and $\mathrm{CD} 20^{+}$, differentiation index) indices.

The investigations were conducted with adherence to General Ethical Principles for Experiments on Animals (Ukraine, 2001), which is in agreement with the Law of Ukraine On Protection of Animals from Cruelty No. 3447-IV dated February 21, 2006 and the provisions of the European Convention for Protection of Animals Used for Experimental and Other Scientific Purposes.

The anatomic level of investigation involved: slaughter and exsanguination of birds; opening of thoracoabdominal cavities; preparation of organs with subsequent extraction from the cavity. The slaughter of 8-, 20-, 40-, 90- and 110-day-old chickens was done by the method of acute exsanguination after ether anesthesia.

The histological investigations were conducted by common methods of tissue fixation and preparation of histological sections (Goralskyy L et al 2015). 
The immunohistochemical investigations were conducted on the basis of pathomorphological laboratory of CSD HEALTH CARE LLC, Kyiv, Ukraine. In the immunohistochemical investigations, $\mathrm{CD}^{+}$(T-helpers), $\mathrm{CD}^{+}$(T-cytotoxic cells), CD45RA ${ }^{+}$(naive T-helpers, B-lymphocytes and monocytes), $\mathrm{CD} 20^{+}$(mature $\mathrm{B}-$ lymphocytes) were labeled in paraffin sections using monoclonal antibodies and visualization system (all the reagents were produced by DAKO company, Denmark). The material for investigation was fixed in $10 \%$ solution of buffered neutral formalin (Shandon Fixx, USA) for $24 \mathrm{~h}$.

After dehydration, the material was poured into highly purified paraffin with polymer additives (Richard-Allan Scientific, USA) at the temperature not exceeding $60{ }^{\circ} \mathrm{C}$. The tissue sections of $5 \mu \mathrm{m}$ were done from paraffin blocks on the rotary microtome Microm HM325 (Carl Zeiss, Germany), placed on specimen slides (Menzel, Germany) and stained by standard methods using hematoxylin and eosin (Kaltek, Italy). For further immunohistochemical investigations, some paraffin sections were placed on adhesive-covered slides of Super Frost Plus (Menzel, Germany). The investigations were conducted using deparaffinized and rehydrated sections.

The method of thermal treatment of sections in Target Retrieval Solution High pH buffer (DAKO, Denmark) was used for tissue antigen retrieval via processing in PT Modul (DAKO, Denmark) for $32 \mathrm{~min}$ at $98-99{ }^{\circ} \mathrm{C}$. Primary antibodies were applied after blocking nonspecific binding of proteins using the protein block (Diagnostic Biosystems, USA) and after blocking endogenous peroxidase activity with the peroxidase block (Diagnostic Biosystems, USA).

The visualization of primary antibodies was conducted using the DAKO EnVision FLEX + detection system (DAKO, Denmark). To visualize the histological structure of the tissue under investigation, the processed immunohistochemical preparations were additionally stained with hemalum for 1-3 min (DAKO, Denmark) with subsequent placement of the stained sections into the Eukitt medium (Germany). The optic investigations of the preparations were conducted using the Olympus AX70 microscope (Japan) with the digital videocamera Olympus DP50, connected to the personal computer. The content, placement and number of lymphocyte subpopulations were determined (per conditional unit of area at the magnification of $\times 400$ ). The quality indices of marker expression were studied using 10 randomly selected fields of microscope vision of histological sections at the magnification of $\times 400$, $\times 600, \times 800$, and $\times 1000$. The differentiation index (DI) - immunoregulatory index - was determined as the quantitative ratio between lymphocytes and antigenic determinants $\mathrm{CD} 4^{+}: \mathrm{CD} 8^{+}$.

The morphometric methods were used to obtain objective data about the structural organization of the harderian gland in chickens (Goralskyy L et al 2015). The studies were performed using light microscopes MBS-10, Micros MC-50. The ratio of lymphoid formations, secretory lobules and connective tissue foundation of the harderian gland was determined using the MBS-10 microscope graticule (squared grids). Using the same magnification, the number of squares, covered with the histostructure under investigation, was estimated in all the chickens, and the percentage ratio of the required index was determined by the ratio between its area, taken on the section surface, and the total area.

The microphotography of the histological preparations was conducted using the digital camera, installed into Primo Star microscope (Carl Zeiss, Germany) and connected to the personal computer.

The statistical processing of the obtained results was conducted by variation statistics methods using the personal computer and Statistica 6.0 software (StatSoft Inc., CШA) with the consideration of the specificities of statistical methods in medical-biological investigations (Goralskyy L et al 2015). The difference between two values was considered reliable at $\mathrm{P}<0.05 ; 0.01 ; 0.001$.

\section{RESULTS}

The harderian gland (HG) is located in chickens medially regarding the eye bulb, between the orbit and periorbit. It has a protruded and oblate body of irregular form and a duct, which opens into the cavity of the conjunctival sac.

The organometric investigations demonstrated that the absolute weight (AW) of the harderian gland in 8-day-old chickens of the control group was $0.017 \pm$ $\pm 0.0007 \mathrm{~g}$ with further increase up till 40 days: in 20-day-old chickens - up to $0.068 \pm 0.002 \mathrm{~g}$ ( $\mathrm{P}<$ $<0.001)$; in 40-day-old chickens - up to $0.086 \pm$ $\pm 0.002 \mathrm{~g}$. Starting with the age of 90 days, there was a decrease in the AW of HG down to $0.073 \pm 0.004 \mathrm{~g}$ $(\mathrm{P}<0.01)$, and at the age of 110 days this index, compared to the previous group, decreased 1.52 times and amounted to $0.048 \pm 0.002 \mathrm{~g}(\mathrm{P}<0.001)$. 
The relative weight (RW) of 8-day-old chickens in the control group was $0.175 \pm 0.133 \%$. During further development of chickens, the RW of the organ decreased reliably due to progressive growth and development of the bodyweight of birds. As for the aspect of age, the relative weight of the HG in the experimental birds as well as in the control ones was changing synchronously and was directly proportional to the AW of the HG and the weight of birds.

Therefore, according to the organometric investigations, the maximal peaks of the AW of the HG were determined on Day 40 with subsequent decrease in the AW of the HG at the age of 90 days, which is remarkable for the development of involutional processes in the organ. The maximal indices of the relative weight of the HG of 8-day-old chickens demonstrate the progressive tempo of the HG growth during the first week of life in terms of the tempo of growth and development of the bodyweight of chickens.

On the outside, the gland is covered with a connective tissue capsule, from which the septa go inside the organ. Collagen fibers were found in the interlobular connective tissue while doing van Gieson's staining (Fig. 1).

The histological investigation of the HG of 8- and 20-day-old chickens, vaccinated against AIB, demonstrated that the septa clearly divided the gland parenchyma into secretory lobules. However, compared to the 8-day-old chickens, the epithelium of the glandular part of the HG in 20-day-old chickens had more expressed structure and was evenly taking up the staining while the histopreparations were treated with hematoxylin and eosin. Gland ducts contained an insignificant amount of the secretion.

The histoarchitecture of the HG of the experimental 8- and 20-day-old chickens had practically no differences from the control birds. After triple vaccination, 40-day-old chickens had lymphoid formations in their $\mathrm{HG}$, which were presented with diffuse and modular forms of lymphoid tissue. During this age period, a reliable increase in the area of lymphoid formations was also observed in the experimental group: 1.14 times $(\mathrm{P}<0.01)$ compared to the control. For instance, if this index was $5.46 \pm 0.14 \%$ in the control group, in the experimental group it was $-6.25 \pm 0.12 \%$.

After the vaccination against infectious bronchitis, 90- and 110-day-old chickens had an increase in the lymphoid tissue and the areas of its penetrating into the secretory part of the gland were detected (Fig. 2).

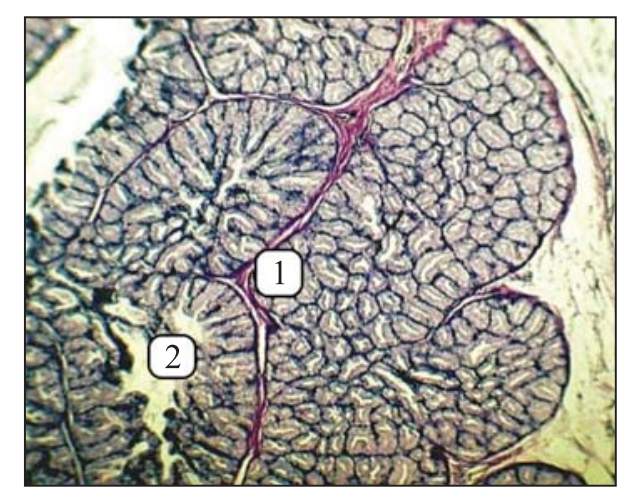

Fig. 1. The microscopic structure of the harderian gland of a 20-day-old chicken from the control group: 1 - secretory lobule; 2 - interlobular connective tissue. Van Gieson's staining. $\times 100$

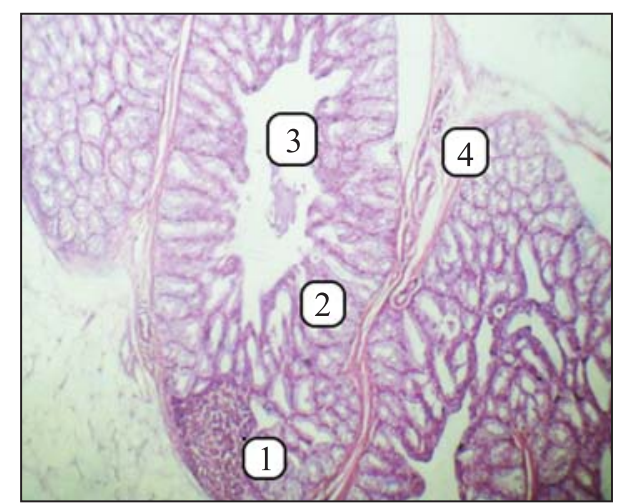

Fig. 2. The microscopic structure of the harderian gland of a 90-day-old chicken from the experimental group: 1 - lymphoid formations; 2 - secretory lobule; 3 - lobular lumen; 4 -interlobular connective tissue. Ehrlich's hematoxylin and eosin. $\times 100$

According to the morphometric investigations, the 110-day-old chickens of the experimental group had a reliable 1.11-fold increase in the area of lymphoid formations in the HG compared to the control, which amounted to $8.47 \pm 0.27 \%(\mathrm{P}<0.05)$.

The immunohistochemical investigations allowed determining natural T-helpers in the HG of the vaccinated 20-day-old chickens only, whereas these were not found in 8-day-old experimental chickens. At the same time, after revaccination single lymphocytes with $\mathrm{CD} 4^{+}$markers were found in the secretory part of the gland of the experimental chickens. As for 40-, 90- and 110-day-old experimental chickens, $\mathrm{CD}^{+}{ }^{+}$-lymphocytes were located in the interlobular connective tissue, near the formed lymph nodules. Here the number of cells, expressing marker $\mathrm{CD}^{+}$, in 20 -day-old vaccinated chickens had a reliable $(\mathrm{P}<0.001) 1.66$-fold increase, in 40-day-old chickens - 1.62-fold increase, 


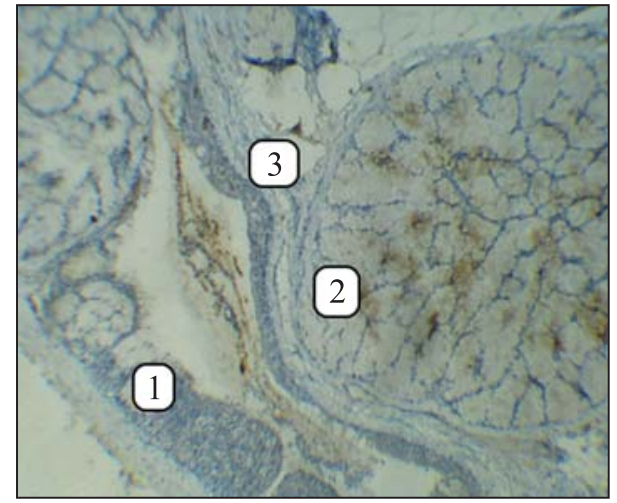

Fig. 3. CD45RA $\mathrm{A}^{+}$-lymphocytes in the harderian gland of a 90-day-old chicken from the experimental group: 1 - lymphoid formations; 2 - secretory lobule; 3 -interlobular connective tissue. The histopreparations with monoclonal antibodies with additional staining using hemalum. $\times 100$

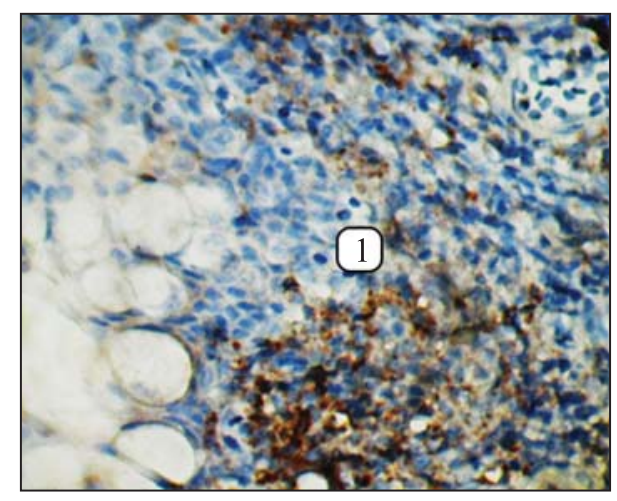

Fig. 4. CD20 -lymphocytes in the harderian gland of a 90-day-old chicken from the experimental group: 1 - lymphoid formations. The histopreparations with monoclonal antibodies with additional staining using hemalum. $\times 400$

in 90-day-old chickens - 1.97-fold and in 110-day-old chickens - 1.9-fold increase compared to the control.

No lymphocytes with $\mathrm{CD}^{+}$markers were found in the HG of 8- and 20-day-old vaccinated chickens. At the same time, staining HG histopreparations of the 40-, 90-, and 110-day-old vaccinated chickens using the antibodies for $\mathrm{CD}^{+}$marker allowed determining T-lymphocytes in the secretory lobules of the gland. Here the localization and placement of T-lymphocytes with $\mathrm{CD}^{+}$markers were similar to those in the control chickens. According to the cytomorphometric investigations, the number of T-lymphocytes with $\mathrm{CD} 8^{+}$ markers in the $\mathrm{HG}$ of the experimental chickens had a reliable increase $(\mathrm{P}<0.001)$ compared to the intact birds respectively: 40-day-old -2.11 -fold, 90-day-old 2.38 and 110-day-old vaccinated chickens - 2.96fold. In 40-day-old chickens of the control group this index was $8.38 \pm 0.38$, whereas in the vaccinated ones $-17.66 \pm 0.73$.

Here, multiple vaccination against infectious bronchitis leads to the decrease in the index of differentiating the lymphocytes of the HG which, in our opinion, demonstrates the development of immunosuppression in the vaccinated chickens.

Single cells with CD45RA ${ }^{+}$markers were determined in the $\mathrm{HG}$ of the 8-day-old vaccinated chickens, whereas their considerable accumulation was noted in 40and 90-day-old chickens, in the interlobular connective tissue and secretory lobules of the organ (Fig. 3). Here their number was considerably higher compared to the control birds.

According to the data of immunohistochemical investigations, single lymphocytes with $\mathrm{CD} 20^{+}$markers were noted in the interlobular connective tissue of the gland of vaccinated 8- and 20-day-old chickens. After three, four and five vaccinations against IB in 40-, 90and 110-day-old chickens respectively, B-lymphocytes were found in the interlobular connective tissue, secretory lobules, diffuse lymphoid tissue, and they formed insignificant accumulations or were separately located in the cytopopulation of the formed lymph nodules (Fig. 4).

The cytomorphometric investigations established that the number of subpopulations of lymphocytes with $\mathrm{CD} 20^{+}$markers in the HG of the vaccinated 8-, 20-, 40-, 90-, and 110-day-old birds had a reliable increase $(\mathrm{P}<0.001)$ compared to the non-vaccinated chickens $1.96,2.04,1.31,1.95$ and 1.84 times respectively.

Therefore, our investigations demonstrated that the vaccination of chickens stimulated the development of immune formations. This is manifested in the formation of lymph nodules and the increase in their area in the harderian gland, especially in 40, 90- and 110-dayold chickens.

\section{DISCUSSION}

Summarizing the results of the investigations, it should be noted that in case of vaccination against infectious bronchitis the character of morphological, histological, morphometric and immunohistochemical changes in the harderian gland of chickens is manifested more vividly at the age of 40 and 90 days. Post-vaccine changes in the histoarchitecture and morphometric indices, found by us in the harderian gland of the experimental chickens, were caused by the age-related specificities of the birds in the postnatal period of ontogenesis and were directly related to the number of 
vaccinations. In addition, the structural changes in the gland demonstrate the formation of humoral and cellmediated immunity in vaccinated chickens.

Our immunocytochemical investigations confirm the data of the authors, stating that the vaccination programs are capable of inducing high levels of $\mathrm{CD}^{+}$, $\mathrm{CD}^{+}$(Awad F et al 2016). Natural T-helpers were found in the harderian gland of the 20-day-old vaccinated chickens, but these were not observed in experimental 8-day-old birds. According to the cytomorphometric investigations, the number of subpopulations of lymphocytes with $\mathrm{CD} 8^{+}$markers in the $\mathrm{HG}$ of the vaccinated chickens had a reliable increase $(\mathrm{P}<0.001)$ compared to the intact birds: in 40-day-old chickens 2.11 times, in 90-day-old chickens - 2.38 times, and in 110-day-old chickens - 2.96 times. The cytophotometric analysis, which is an objective criterion of estimating quantitative indices, proved that the number of mature B-lymphocytes $\left(\mathrm{CD} 20^{+}\right)$was characterized by a reliable $(\mathrm{P}<0.001)$ increase in the $\mathrm{HG}$ of vaccinated chickens of different age. The results of our investigations confirm the data of the authors, stating that the cell-mediated immune response in the lymphoid formations of immune protection organs is a prerequisite for humoral responses. Their insufficiency in birds during the first weeks of life is related to the immaturity of T- and B-lymphocytes therein (Gomez D et al 1998).

Despite numerous data about pathologo-anatomic changes during avian infectious bronchitis (Cook $\mathrm{J}$ et al 2012, Cavanagh D et al 2007), its pathomorphology is yet to be studied in fine detail, and sometimes these data are contradictory.

\section{CONCLUSIONS}

The application of vaccination against infectious bronchitis stimulates the development of immune formations, which is manifested in the increase in the number and sizes of lymph nodules in the harderian gland, which facilitates the enhanced activity of the immunity against infectious bronchitis. Chickens, vaccinated against infectious bronchitis, demonstrate enhanced activity of their humoral immunity, characterized by the increase in B-lymphocytes with CD20 markers in the harderian gland. The number of subpopulations of lymphocytes with $\mathrm{CD} 20^{+}$markers in the gland of vaccinated 8-, 20-, 40-, 90-, and 110-day-old birds had a reliable increase $(\mathrm{P}<0.001)$ compared to non-vaccinated birds $-1.96,2.04,1.31,1.95$ and 1.84 times respectively. There was a noted activation of cellmediated immune response due to active increase in T-cytotoxic cells with $\mathrm{CD}^{+}$markers. For instance, in 40-day-old chickens of the control group, the number of T-lymphocytes with $\mathrm{CD}^{+}$markers was $8.38 \pm 0.38$, whereas the vaccinated ones had $17.66 \pm 0.73$. At the same time, there was a decrease in the immunoregulatory index, which demonstrated the presence of T-cell immunodeficiency condition of helper type by the relative hypercytotoxic variant and indicated the enhanced work of the immune system of the organism to destroy the foreign antigen.

Adherence to ethical principles. The investigations were conducted with adherence to General Ethical Principles for Experiments on Animals (Ukraine, 2001), which is in agreement with the Law of Ukraine On Protection of Animals from Cruelty No. 3447-IV dated February 21, 2006 and the provisions of the European Convention for Protection of Animals Used for Experimental and Other Scientific Purposes.

Conflict of interests. The authors do not have any conflict of interests.

Financing. The investigation was conducted at the support of the state fund, scientific project "Morphology, immunology of coronavirus infections (avian infectious bronchitis, canine coronavirus), their diagnostics and prevention", state registration No. 0118U003815.

\section{МОРФОФУНКЦІОНАЛЬНИЙ СТАН ГАРДЕРОВОЇ ЗАЛОЗИ КУРЕЙ У ПЕРІОД ПОСТВАКЦИНАЛЬНОГО IМУНІТЕТУ ПРОТИ ІНФЕКЦІЙНОГО БРОНХІТУ}

С. В. Гуральська, Т. Ф. Кот, О. В. Пінський, В. М. Соколюк, Т. С. Буднік

Житомирський національний агроекологічний університет, Житомир, Україна

Старий бульвар, 7, м. Житомир, 10008

e-mail: guralska@ukr.net*,tkotvet@ukr.net, pinsky.o.v@gmail.com,vmsokoluk@gmail.com, tatjanabudnik@ukr.net

Мета. 3'ясувати вміст та розміщення субпопуляцій $\mathrm{CD}^{+}$, $\mathrm{CD}^{+}, \mathrm{CD}_{4} 5 \mathrm{RA}^{+}, \mathrm{CD} 20^{+}$-лімфоцитів та морфоцитохімічну архітектоніку гардерової залози у клінічно здорових курей та за вакцинації проти інфекційного бронхіту. Методи. Анатомічні, гістологічні, імуногістохімічні, світлооптичні, морфометричні, варіаційно-статистичні. Результати. Отримані результати морфометричного дослідження показали, що площа лімфоїдних утворень та секреторних часточок значно більша в гардеровій залозі вакцинованих курей 40, 90 та 110-добового віку. Причому, розмір органа значно корелює 3 розвитком лімфоїдних утворень, оскільки площа часточок секреторного відділу залози курей дослідної групи не відрізняється від показників контрольної групи. Імуногістохімічними дослідженнями доведено, що кількість 
GURALSKA et al.

лімфоцитів з маркером $\mathrm{CD} 20^{+}$характеризувалась вірогідним (P < 0,001) збільшенням В-лімфоцитів у гардеровій залозі вакцинованих курей різного віку. Лімфоцитів з маркерами $\mathrm{CD}^{+}$в залозі вакцинованих курей 8 та 20-добового віку не виявляли. Згідно 3 цитоморфометричними дослідженнями, їх кількість у вакцинованих курей 40, 90 та 110-добового віку вірогідно (P $<0,001)$ зросла порівняно 3 інтактною птицею в $2,11,2,38$ та 2,96 рази відповідно. Висновки. Отримано дані про склад лімфоцитів 3 маркерами $\mathrm{CD}^{+}, \mathrm{CD}^{+}$,

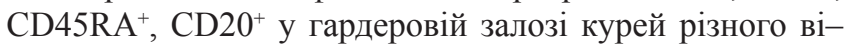
ку, зміни їх у разі імунізації проти інфекційного бронхіту i, як наслідок, визначена роль певних кластерів на різних етапах формування імунітету. Доповнено відомості про структуру, закономірності росту й розвитку гардерової залози курей, які свідчать про незавершеність їі морфогенезу до 20-добового віку, що необхідно враховувати під час складання програм вакцинопрофілактики.

Ключові слова: патоморфологія, натуральні Т-хелпери, Т-цитотоксичні клітини, імунодефіцитний стан хелперного типу, гуморальний імунітет, чужорідний антиген, вакцинація.

\section{Морфофункциональное состояние гардеровой железы кур в период поствакцинального иммунитета против инфекционного бронхита}

\author{
С. В. Гуральская, Т. Ф. Кот, О.В.Пинский,
} В. М. Соколюк, Т. С. Будник

\section{Житомирский национальный агроэкологический университет, Житомир, Украина \\ Старый бульвар, 7, Житомир, 10008 \\ e-mail: guralska@ukr.net*,tkotvet@ukr.net, pinsky.o.v@gmail.com,vmsokoluk@gmail.com, tatjanabudnik@ukr.net}

Цель. Выяснить содержание и размещение субпопуляций $\mathrm{CD}^{+}, \mathrm{CD}^{+}, \mathrm{CD} 45 \mathrm{RA}^{+}, \mathrm{CD} 20^{+}$-лимфоцитов и морфоцитохимическую архитектонику гардеровой железы у клинически здоровых кур и при вакцинации против инфекционного бронхита. Методы. Анатомические, гистологические, иммуногистохимические, светооптические, морфометрические, вариационно-статистические. Результаты. Полученные результаты морфометрического исследования показали, что площадь лимфоидных образований и секреторных долек значительно больше в гардеровий железе вакцинированных кур 40, 90 и 110-суточного возраста. Причем, размер органа значительно коррелирует с развитием лимфоидных образований, поскольку площадь частиц секреторного отдела железы кур опытных групп не отличается от показателей контрольной группы. Иммуногистохимическими исследованиями доказано, что количество лимфоцитов с маркером $\mathrm{CD} 20^{+}$характеризовалась достоверным (P <
$<0,001)$ увеличением В-лимфоцитов в гардеровой железе вакцинированных кур разного возраста. Лимфоцитов с маркерами $\mathrm{CD}^{+}$в железе вакцинированных кур 8 и 20-суточного возраста не обнаруживали. Согласно цитоморфометричным исследованиям, их количество у вакцинированных кур 40, 90 и 110-суточного возраста достоверно (P $<0,001)$ увеличилось по сравнению с интактной птицей в 2,11, 2,38 и 2,96 раза соответственно. Выводы. Получены данные о составе лимфоцитов с маркерами $\mathrm{CD}^{+}, \mathrm{CD}^{+}, \mathrm{CD} 45 \mathrm{RA}^{+}, \mathrm{CD} 20^{+}$в гардеровой железе кур разного возраста, изменения их в случае иммунизации против инфекционного бронхита и, как следствие, определенна роль определённых кластеров на различных этапах формирования иммунитета. Дополнены сведения о структуре, закономерности роста и развития гардеровой железы кур, которые свидетельствуют о незавершенности ее морфогенеза до 20 суточного возраста, что необходимо учитывать при составлении программ вакцинопрофилактики.

Ключевые слова: патоморфология, натуральные Т-хелперы, Т-цитотоксические клетки, иммунодефицитное состояние хелперного типа, гуморальный иммунитет, чужеродный антиген, вакцинация.

\section{REFERENCES}

Alazawy AKS, Abdulhussain SR, Nasser AT et al. (2017) Serological Survey and Molecular Detection of Infectious Bronchitis Virus in Broiler Chickens in Diyala Province, Iraq. Poult. Sci. 16:88-92. doi:10.3923/ijps.2017.88.92.

Ali A, Kilany WH, Zain El-Abideen MA et al. (2018) Safety and efficacy of attenuated classic and variant 2 infectious bronchitis virus candidate vaccines. Poult. Sci. 1;97(12):4238-44. doi:10.3382/ps/pey312.

Awad F, Hutton S, Forrester A et al. (2016) Heterologous live infectious bronchitis virus vaccination in day-old commercial broiler chicks: clinical signs, ciliary health, immune responses and protection against variant infectious bronchitis viruses. Avian. Pathol. 45(2):169-77. doi: 0.1080/03079457.2015.1137866.

Ball C, Awad F, Hutton S et al. (2017) Infectious bronchitis vaccine virus detection and part-S1 genetic variation following single or dual inoculation in broiler chicks. Avian. Pathol. 46(3):309-18. doi:.10.1080/03079457.2016.126 8675.

Bande F, Arshad SS, Bejo MH et al. (2015) Progress and challenges toward the development of vaccines against avian infectious bronchitis. J. Immunol. Res. doi: 10.1155/2015/424860.

Bande F, Arshad SS, Omar AR et al. (2017) Global distributions and strain diversity of avian infectious bronchitis virus: a review. Anim. Health. Res. Rev. 18(1):7083. doi: $10.1017 / \mathrm{S} 1466252317000044$.

Bru T, Vila R, Cabana M, Geerligs HJ. (2017) Protection of chickens vaccinated with combinations of commercial live infectious bronchitis vaccines containing Massa- 
chusetts, Dutch and QX-like serotypes against challenge with virulent infectious bronchitis viruses 793B and IS/1494/06 Israel variant 2. Avian. Pathol. 46(1):52-8. doi: 10.1080/03079457.2016.1203393.

Cavanagh D. (2007) Coronavirus avian infectious bronchitis virus. Vet. Res. 38(2):281-97. doi: 10.1051/vetres: 2006055.

Cook JKA, Jackwood M, Jones RC. (2012). The long view: 40 years of infectious bronchitis research. Avian. Pathol. 41:239-50. doi: 10.1080/03079457.2012.680432.

Gomez DMM, Fonfria J, Varas A et al. (1998) Appearance and development of lymphoid cells in the chicken (Gallus gallus) caecal tonsil. Anat. Rec. 250(2):182-9. doi: 10. 1002/(SICI)1097-0185(199802)250:2<182::AIDAR8>3.0.CO;2-5.

Goralskyy LP, Khomych VT, Kononskyy OI. (2015) Osnovy histolohichnoyi tekhniky i morfofunktsionalni metody doslidzhennya u normi ta pry patolohiyi [Fundamentals of histological technology and morphofunctional methods of research in norm and pathology]. Zhytomyr: Polissya.

Guralska S, Budnik T. (2020) The morphology of the harderian gland chicken's for vaccination and application of Avesstim ${ }^{\mathrm{TM}}$. Scientific Horizons 01 (86), 79-88. doi: 10.33249/2663-2144-2020-86-1-79-88.

Gurjar RS, Gulley SL, van Ginkel FW. (2013) Cell-mediated immune responses in the head-associated lymphoid tissues induced to a live attenuated avian coronavirus vaccine. Dev. Comp. Immunol. 41(4):715-722. doi: 10. 1016/j.dci.2013.08.002.

Habibi M, Karimi V, Langeroudi AG et al. (2017) Combination of $\mathrm{H} 120$ and 1/96 avian infectious bronchitis virus vaccine strains protect chickens against challenge with IS/1494/06 (variant 2)-like infectious bronchitis virus. Acta Virol. 61(2):150-60. doi: 10.4149/av_2017_02_04.

Jahan MR, Islam MN, Khan MZI, Yanai A, Shinoda K. (2018) Morphometry and expression of immunoglobulins-con- taining plasma cells in the Harderian gland of birds. J. Adv. Biotechnol. Exp. Ther. 1(2):55-60.

Jahan MR, Khan MZI, Islam MN and Akter SH. (2006) Morphometrical analysis of Harderian gland of broiler and native chickens of Bangladesh. J. Bangladesh. Agril. Univ. 4(2):273-8.

Jia Z, Cao Y, Xue Y et al. (2014) Analysis of Chicken T CellMediated Responses on Thymus after Immune Stress. J. Immun. Bas. Therap. Vac. Antimicrob. 3:22-8. doi: 10.4236/jibtva.2014.32003.

Karimi V, Mohammadi P, Ghalyanchilangeroudi A et al. (2019) Including 793/B type avian infectious bronchitis vaccine in 1-day-old chicken increased the protection against QX genotype. Trop. Anim. Health. Prod. 51(3):629-35. doi: 10.1007/s11250-018-1730-4.

Khan M ZI, Jahan MR, Islam MN et al. (2007) Immunoglobulin (Ig)-containing plasma cells in the Harderian gland in broiler and native chickens of Bangladesh. Tiss. Cell. 39:141-9. doi: 10.1016/j.tice.2007.02.005.

Ovchinnikova EV, Bochkov YuA, Shcherbakova LO et al. (2011) Molecular characterization of infectious bronchitis virus isolates from Russia and neighbouring countries: identification of intertypic recombination in the S1 gene. Avian. Pathol. 40(5):507-14. doi: 10.1080/ 03079457.2011.605782.

Sarah EA, Helmy AT, Seddeek ME. (2014) Antigenic Variations of Infectious Bronchitis Virus from Broiler flocks in Al Behera Governorate. AJVS. 40:44-51. doi: 10.5455/ajvs.46652.

Valastro V, Holmes EC, Britton P et al. (2016) S1 gene-based phylogeny of infectious bronchitis virus: an attempt to harmonize virus classification. Infect. Genet. Evol. 39:349-64. doi: 10.1016/j.meegid.2016.02.015.

Zhao W, Gao M, Xu Q et al. (2017) Origin and evolution of LX4 genotype infectious bronchitis coronavirus in China. Vet. Microbiol. 198:9-16. doi: 10.1371/journal. pone. 0144179 . 